\title{
Faculdade
}

de Ciências Econômicas UFRGS
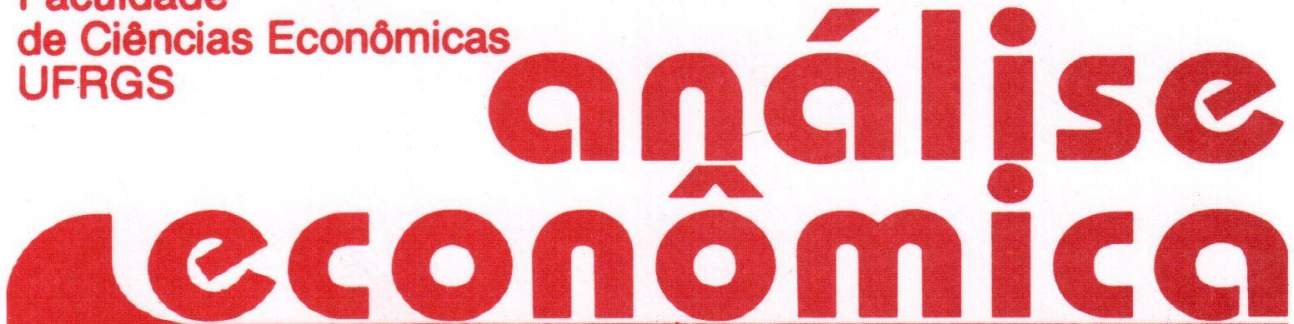

- HIPERINFLAÇÃo E A FORMA FUNCIONAL DA DEMANDA DE MOEDA Fernando de Holanda Barbosa

- AJUSTE Y REFORMA ESTRUCTURAL EN ARGENTINA, 1989/93 Gustavo Ferro

- MUdANÇAS NA ESTRUTURA do COMÉRCIO EXTERNO BRASILEIRO Álvaro Barrantes Hidalgo

- EQUILIBRIUM MODELS OF TRADE EQUATIONS: A CRITICAL REVIEW Marcelo S. Portugal

- THE THEORY OF FREE BANKING Anna J. Schwartz

- ARE BANKING CRISES A FREEMARKET PHENOMENON? George Selgin

- tamanho de estabelecimento AGRICOLA E PRODUTIVIDADE. Paulo D. Waquil

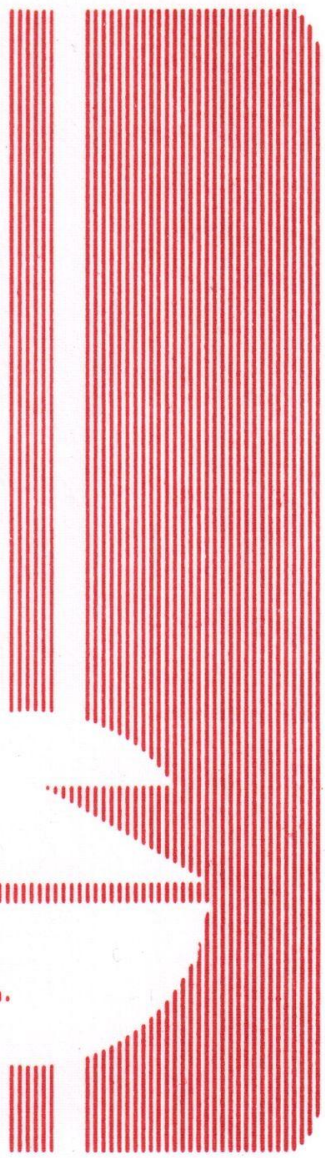


UNIVERSIDADE FEDERAL DO RIO GRANDE DO SUL

Reitor Prof Hélgio Henrique Casses Trindade

FACULDADE DE CIÊNCIAS ECONÓMICAS

Diretor. Prof Pedro Cézar Dutra Fonseca

CENTRO DE ESTUDOS E PEQUISAS ECONÔMICAS

Diretor: Prof. Roberto Pires Pacheco

DEPARTAMENTO DE CIÉNCIAS ECONÓMICAS

Chefe: Prof Fernando Ferrari Filho

CURSO DE PÓS-GRADUAÇÃO EM ECONOMIA

Coordenador: Prof. João Rogério Sanson

CURSO DE PÓS-GRADUAÇÃO EM ECONOMIA RURAL.

Coordenador. Prof. Juvir Luiz Mattuella

CONSELHO EDITORIAL: Achyles Barcelos da Costa, Aray Miguel Feldens, Atos Freitas Grawunder, Carlos Augusto Crusius, Fernando Ferrari Filho, João Rogério Sanson, Juvir Luiz Mattuella, Marcelo Savino Portugal, Maria Imilda da Costa e Silva, Nali de Jesus de Souza, Nuno R. L. de Figueiredo Pipto, Otília Beatriz K. Carrion, Paulo Alexandre Spohr, Pedro Cezar Dutra Fonseca, Roberto Camps Moraes, Valter José Stülp, David Garlow (Wharton Econometrics Forecasts Assoc, E. U.A.), Edgar Augusto Lanzer (UFSC), Eleutério F. S. Prado (USP), Fernando de Holanda Barbosa (FGV/RJ), Gustavo Franco (PUC/RJ), Joaquim Pinto de Andrade (UnB), Juan. H. Moldau (USP), Werner Baer (Univ de lllinois, E U A)

COMISSÃO EDITORIAL: Atos Freitas Grawunder, Pedro Cezar Dutra Fonseca, Marcelo Savino Portugal, Nali de Jesus de Souza.

EDITOR: Roberto Camps Moraes

SECRETARIA: Rosângela Ellwanger Soares (Secretária), Vanete Ricachescki (revisão de textos)

FUNDADOR: Prnf. Antônio Carlos Santos Rosa

Os materiais publicados na revista Análise Econômica são da exclusiva responsabilidade dos autores. É permitida a reprodução total ou parcial dos trabalhos, desde que seja citada a fonie. Aceita-se permuta com revistas congêneres. Aceitam-se, também, iivros para divulgação, elaboração de resenhas e recensões. Toda correspondência, material para publicação (vide normas na terceira capa), assinaturas e permutas devem ser dirigidos ao seguinte destinatário:

PROF. NALI DE JESUS DE SOUZA

Revista Análise Econômica

Av. João Pessoa, 52

CEP 90040-000 PORTO ALEGRE - RS, BRASIL

E-MAIL: NALI@VORTEX.UFRGS.BR

Telefones: (051) 316-3348 e 316-3440

Fax (051) 225-1067 


\section{EQUILIBRIUM MODELS OF TRADE EQUATIONS: A CRITICAL REVIEW}

Marcelo S Portugal

\section{ABSTRACT}

In this paper we review the theoretical literature on trade equation models, including the production theory approach. We discuss several empirical problems commonly found in the applied work and the available literature on Brazilian trade equations.

\section{INTRODUCTION}

in this paper we will address the question of how to model trade equations. We will discuss not only the theoretical aspects but also some of the applied work using Brazilian data. For space reasons we will restrict our attention to equilibrium models.

We will deal as well with some of the practical econometric problems involved such as which variables to use, how to model the dynamics, parameter instability and stationarity.

All empirical work on Brazilian trade equations to date have assumed that the parameters are constant. This may be an unrealistic assumption, if price and income elasticities in trade equations vary not only cyclically, according to movements in the business cycle, but also as a result of the implementation of different trade policies or changes in the pattern of trade due to the process of economic development. Such parameter instability might be particularly expected in the Brazilian case, given that in the last thirty years there have been several abrupt changes in trade policy and two major import substitution programs.

Following this introduction, the paper has three sections. In the next section, we present the main theoretical aspects of trade equation modelling, together with some empirical issues. The third section contains a discussion of the empirical work available on trade equations in Brazil anci the last section presents the conclusions and remarks.

\section{THE SPECIFICATION OF TRADE EQUATIONS}

There are two different approaches to the modelling of trade equations. Tne

\footnotetext{
- From the Federal University of Rio Grande do Sul.

1 The discussion of disequilibrium models can be found in Fair and Jaffee (1972), Fair and Kelejian (1974) and Quandt (1988). An application of such models using Brazilian data is available in Rios (1986) and Fachada (1990).
}

\begin{tabular}{|c|l|}
\hline $\begin{array}{c}\text { Cód. AEA } \\
\mathbf{4 2 0}\end{array}$ & $\begin{array}{l}\text { Palavras-chave: } \\
\text { Trade equations; trade elasticities; Brazilian trade. }\end{array}$ \\
\hline
\end{tabular}

\begin{tabular}{|l|l|l|l|}
\hline ANÁLISE ECONÔMICA & ANC 11 & Setembro/93 & p. 69-91 \\
\hline
\end{tabular}


traditional approach, surveyed by Goldstein and Khan (1985) and Magee (1975), adopts a household model treating traded goods as final goods that enter the consumer sector directly. An alternative approach, surveyed by Woodland (1982) and Kohli (1991), models trade equations from a production theory framework.

\subsection{The production theory approach}

In this model the small country hypothesis is adopted, implying that only import demand and export supply have to be estimated. All imported goods are supposed to be intermediate goods, used by the production sector as inputs. On the other hand, exported and domestic goods are assumed to be separable outputs of the production sector. That is, in this model there is no consumption of traded goods, since all imports are inputs while exported goods are different from domestic production. Duality theory is used to derive econometrically convenient equations.

The model uses a short run or restricted profit function, or GNP function, to represent the technology. Import and export decisions are made by profit maximizing firms under perfect competition conditions. The firms choose the optimum imports and output mix given a vector of domestic and international prices and a vector of domestic primary factor stocks. The technology is represented by a production possibility set from which the profit function can be derived. Therefore, given the production possibility set $T$ we can define the restricted profit function, which has the usual properties, as

$$
p(p, v)=\max x\{p x:(x, v) \in T\}
$$

where $x$ is a vector of net output (imports enter with a negative sign), $v$ is a vector of fixed inputs and $p$ is a positive vector of domestic and international prices. Using Hotelling's Lemma we obtain

$$
\mathrm{x}=\nabla_{\mathrm{p}} \pi(\mathrm{p}, \mathrm{v})
$$

where $\nabla$ is the vector differential operator. Assuming that capital stock is fixed in the short run, the sysiem of equations (1) represents the short run domestir output supply and the short run export supply and import demand functions Similarly, we can obtain the system of inverse demand for domestic primary inputs (if the derivatives exist)

$$
w=\nabla_{v} \pi(p, v)
$$

where $w$ is the vector of factor prices.

To make the model operational we have just to specify a functional form for the profit function. Following Kohli (1978), Burgess (1974a and 1974b) and Lawrence (1987) let us use a translog function defined as

$$
\ln (z)=a_{00}+\sum_{i} a_{i 0} \ln z_{i}+1 / 2 \sum_{i} \sum_{j} a_{i j} \ln z_{i} \ln z_{j}
$$


Using (3) we can write the translog profit function as ${ }^{2}$

$$
\begin{aligned}
\ln \pi= & a+\sum_{i} b_{i} \ln p_{i}+1 / 2 \sum_{i} \sum_{h} c_{i n} \ln p_{i} \ln p_{h}+\sum_{j} d_{j} \ln v_{j}+1 / 2 \sum_{j} \sum_{k} e_{j k} \ln v_{j} \ln v_{k} \\
& +\sum_{i}, \sum_{j} f_{i j} \ln p_{i} \ln v_{j}
\end{aligned}
$$

where $c_{i j}=c_{j i}$ and $e_{j k}=e_{k j}$. To ensure that $\pi$ is homogeneous of degree one in prices requires that

$\sum_{i} b_{i}=1$ and $\sum_{j} f_{i j}=\sum_{h} c_{i h}=0$

while to ensure that $\pi$ is homogeneous of degree one in domestic primary inputs requires that

$\sum_{j} d_{j}=1$ and $\sum_{k} f_{i j}=\sum_{k} e_{j k}=0$

By logarithmic differentiation we obtain

$$
\begin{aligned}
& \frac{\partial \ln \pi}{\partial \ln p_{i}}=p_{i} \frac{\left(\partial \pi / \partial p_{i}\right)}{\pi}=\frac{p_{i} x_{i}}{\pi}=S_{i} \\
& \frac{\partial \ln \pi}{\partial \ln v_{i}}=v_{i} \frac{\left(\partial \pi / \partial v_{j}\right)}{\pi}=\frac{v_{j} w_{i}}{\pi}=s_{i}
\end{aligned}
$$

Applying (7) to (4) we have

$$
\begin{aligned}
& s_{i}=b_{i}+\sum_{h} c_{i n} \ln p_{h}+\sum_{j} f_{i j} \ln v_{j} \\
& s_{i}=d_{j}+\sum_{i} f_{i j} \ln p_{i}+\sum_{k} e_{j k} \ln v_{k}
\end{aligned}
$$

These equations can then be estimated econometrically to obtain the unknown parameters. Note that, since Si and si add up to one, only $n-1$ equations have to de estimated in each system.

One interesting feature of this method is that it allows the estimation of all cross elasticities of the domestic supply, labour demand, import demand and export supply. Moreover, since the functional form chosen for $\pi$ is not a constant elasticity one, these elasticities can be estimated for each point in time

$$
\epsilon_{i j}=\left(p_{j} / x_{i}\right) \partial\left(\partial \pi / \partial p_{i}\right) / \partial p_{j}
$$

\subsection{The perfect and imperfect substitutes models}

In terms of the traditional approach, as shown by Goldstein and Khan (1985) and

2 The choice of functional form is arbitrary. Diewert and Morrison (1989), for example, use a biquadratic restricted profit function. For a catalogue of possible functional forms, see Kohli (1991). 
Magee (1975), there are two different ways to model trade equations, depending on whether domestic and foreign products are assumed to be perfect or imperfect substitutes. In the imperfect substitutes model, the products are supposed to be slightly different, in such a way that prices are also different.

Thus, the demand and supply curves for imported goods can be written as a function of national income, and prices of domestic and imported goods. What is relevant for the importers is not only the prices, but actually the final cost paid by the product measured in a common currency. The demand and supply of imports can then be written as

$$
\begin{aligned}
& M^{d}=f\left(Y_{n}, E P_{m}, P_{d}, T\right), \\
& f_{1}>0, f_{2}<0, f_{3}>0, f_{4}<0 \\
& M^{s}=g\left(P_{m}, P_{d}^{*}, S^{*}, Y_{n}^{*}\right), \\
& g_{1}>0, g_{2}<0, g_{3}>0, g_{4}>0 \\
& M^{d}=M^{s},
\end{aligned}
$$

where $Y_{n}$ is nominal income $P_{m}$ and $P_{d}$ are the import and domestic price levels, $E$ is the nominal exchange rate, $S$ is the rate of export subsidies ${ }^{3}$, and $T$ stands basically for tariff, but should also include transport costs, insurance and all other factors that represent an additional cost for the importer. The asterisk is used to differentiate between the foreign and home economies. The aggregate demand function depends positively on nominal income and domestic prices, and negatively on import prices measured in local currency and the tariff rate, while in the supply function import prices, the foreign subsidy to exports, foreign income have the positive sign, and foreign domestic prices a negative sign.

In the same way, demand and supply for exports can be written as a function of effective prices, including exchange rate and export subsidies, and external income.

$$
\begin{aligned}
& X^{d}=I\left(P_{x}, P_{d}^{*}, Y_{n}^{*}, T^{*}\right), \\
& I_{1}<0, I_{2}<0, I_{3}>0, I_{4}<0 \\
& X^{S}=h\left(E P_{X}, P_{d}, S, Y_{n}\right), \\
& h_{1}>0, h_{2}<0, h_{3}>0, h_{4}>0 \\
& x^{d}=X^{S},
\end{aligned}
$$

where $P_{x}$ is the export price index. The supply of exports depends positively on export prices in terms of domestic currency, export subsidies and domestic income, and negatively on domestic prices, while the demand for exports is positively related to foreign domestic prices and foreign income, and negatively with export prices and tariff rates in the rest of the world.

\footnotetext{
${ }^{3}$ Note that the supply of imports for a counity is aiso the supply of exports from the rest of the world to the country.
} 
As is common in the literature, some additional hypotheses can be used to simplify the model presented above. First, the estimation of supply and demand curves is some times said not to be necessary. If one assumes the supply curves to be completely elastic, only the demand functions have to be estimated. Although it may be possible for a country to buy its imports in the world market without changing the price, the same does not seem plausible for exports. Unless there exists idle capacity, or, more generally, unless the export sector operates subject to constant or increasing returns to scale, it seems unlikely that, at least in the short run, production could be expanded without an increase in prices. In other words, although it is plausible to assume that a country is a price taker in the world market, it is less plausible to assume that the rest of the world is also a price taker with respect to the home economy. One explanation sometimes offered to justify the estimation of demand equations only is that price decisions are taken before the decision on quantities, which "implies that within a range of variation in the data any quantity can be supplied at the given prices". 4

If that is not the case, the import and export prices cannot be treated as exogenous variables, and a simultaneous model must be estimated. The estimation of the demand equation model alone, when the supply curve is not totally elastic, would lead to an inconsistent and downward biased estimate of the price elasticity of demand. The estimated price elasticity of demand would be a weighted average of the actual demand and supply elasticities.

Another way of reducing the number of equations to be estimated is to adopt the "small country" hypothesis. If the country's share in world imports and exports is small, the supply of imports and the demand for exports wili be completely price elastic or, at least have a substantially high price elasticity. Thus, the import and export volumes will depend only on the demand for imports and supply of exports functions, since the country will be able to buy its imports and sell its exports with no feedback on prices. If that is not the case, once again a simultaneous model must be estimated, otherwise the coefficients will be inconsistent and biased.

In the literature on trade equations it has been common to adopt the "small country" hypothesis for imports, estimating only a demand equation, while in the case of exports the use of a simultaneous approach has often been preferred

A second supposition, common not only in work on trade eq! lations but also in consumer theory as a whole, is the absence of money illusion. This assumption implies that the functions are homogeneous of degree zero in prices and nominal income. One can then normalise the variables by the domestic price level, using real income and relative prices as explanatory variables

Another possible simplification is to combine prices and tariffs or subsidies into a single variable. Sometimes it is argued that tariff and import prices have different effect on imports. This could result from importers regarding changes in tariff as permanent, while changes in import prices are regarded as temporary, or from the fact that changes in tariff are usually announced in advance. ${ }^{5}$ The same line of argument applies to export subsidies. In the case of tariffs, empirical work has shown that import prices and tariffs have equal effect on import demand ${ }^{6}$

${ }^{4}$ Barker (1987), p. 203.

5 See, for example, Balassa (1967)

${ }^{6}$ See Hitiris and Petoussis (1984). 
The previous model can then be rewritten as

$$
\begin{aligned}
& M^{d}=f\left(Y, E P_{m}(1+T) / P_{d}\right) \\
& f_{1}>0 f_{2}<0 \\
& M^{s}=g\left(Y^{*}, P_{m}(1+T) / P_{d}^{*}\right) \\
& g_{1}>0 g_{2}>0 \\
& X^{d}=I^{*}\left(Y^{*}, P_{X}\left(1+T^{*}\right) / P_{d}^{*}\right), \\
& I_{1}>0 I_{2}<0 \\
& X^{s}=h\left(Y, E P_{X}(1+S) / P_{d}\right) . \\
& h_{1}>0 h_{2}<0
\end{aligned}
$$

Until now we have dealt witi equilibrium models. The disequilibrium models applied to trade equations that are available in the literature are generally of a very simple fashion. It is normally assumed that the optimum and actual levels of imports or exports are different. A partial adjustment model is then proposed to model the disequilibrium. $^{\text {? }}$

More recently, other kinds of disequilibrium models have been proposed. These models follow the work of Fair and Jaffee (1972), Fair and Kelejian (1974) and Maddala (1986). The idea is to divide the sample into points on the demand and supply curves. Although the maximum likelihood approach to the sample separation problem is more efficient, simple methods using the price variation are often used Rios (1986) and Fachada (1990), for example, have used the methods proposed by Fair and Jaffee (1972) to estimate a disequilibrium model for the Brazilian exports.

On the other hand, if domestic and foreign goods are assumed to be perfect substitutes, having a common price given by world supply and demand, price differentials will play no role in determining the volume of trade In this case, imports and exports couid be modelled as the difference between domestic dernand and supply.

Let $D$ and $S$ be the total domestic demand and supply of the traded good, $P_{d}$ is the domestic price, $Y$ is real income and $F$ is some cost variable. ${ }^{8}$ Then the perfect substitutes model can be written as

$$
\begin{aligned}
& D=f\left(P_{d}, Y\right) \\
& f_{1}<0 f_{2}>0 \\
& S=g\left(P_{d}, F\right) \\
& g_{1}>0 g_{2}<0
\end{aligned}
$$

7 See, for example, Goldstein and Khan (1978) and Khan (1974).

8 In this case, as Enoch (1978) shows, a possible measure of competitiveness is relative costs instead of relative prices. 


$$
\begin{aligned}
& M=D\left(P_{d}, Y\right)-S\left(P_{d}, F\right) \\
& X=S\left(P_{d}, F\right)-D\left(P_{d}, Y\right)
\end{aligned}
$$

One should note that in this case there are no explicit demand for imports or supply for exports. The model describes only excess demand, and excess supply of domestic goods, assumed to be satisfied by imports and exports. The country's ability to influence world prices will depend basically on its share of the world market and on its own price elasticity of supply and demand.

The choice of the perfect or imperfect substitute model will depend essentially on the kind of product or the level of aggregation we are considering. For manufactured goods or aggregates such as consumer and capital goods, the imperfect substitute model seems adequate, while for homogeneous goods such as crude oil, wheat or coffee the perfect substitute model is more appropriate. ${ }^{9}$

\subsection{Other variables of interest}

\subsubsection{Import equations}

It is common place in the empirical literature on import demand to include some other variables to account for non-price restrictions, differences between the cyclical and secular income elasticities, and for long run trends in the volume of imports. ${ }^{10}$

In the case of non-price restrictions, the basic argument is that there aie extra costs that are not normally reflected in movements of prices. Depending on which phase of the business cycle the economy is in, delivery lags can change considerably, leading to an increase or decrease in imports. To deal with this problem, it is common to introduce a capacity variable such as $Y / Y^{P}$, where $Y$ and $Y^{P}$ are respectively actual and potential output. Thus, when the economy is overheated, imports tend to increase, whereas in a phase of widespread spare capacity the volume of imports should decrease

Another point, raised by Khan and Ross (1975), is that one should distinguish between cyclical and secular effects on the demand for imports. They claim basically that one should use not only actual income as an explanatory variable, but also its poteirial value. Their model is a kind of partial adjustment model, where current imports depend on current income and the "potential demand for imports" or, in other words, the long run demand for imports, depend on the potential income. Then, by using a partial adjustment hypothesis, where deviations between the actual and potential demand for imports are a fraction of the deviation between actual and potential income, they end up with an equation in terms of price, actual real income and its potential value in analytical terms

$$
\begin{aligned}
& \ln M^{d}=a_{0}+a_{1} \ln P_{t}+a_{2} \ln y_{t}+u_{t} \\
& \ln M^{p d}=b_{0}+b_{1} \ln P_{t}+b_{2} \ln Y_{t}^{p}+v_{t} \quad \text { and }
\end{aligned}
$$

\footnotetext{
9 Such models have been applied to the Brazilian imports of crude oil and wheat by Ramos (1985) and Modiano (1983).

to See Barker (1979), Khan and Poss (1975) and Barker (1987)
} 
$\ln M_{t}^{d}-\ln M_{t}^{p d}=d\left(\ln y_{t}-\ln y_{t}^{p}\right)+w_{t}$

Substituting (24) into (25) we get the estimating equation

$\ln M_{t}^{d}=b_{0}+b_{1} \ln P_{t}+d \ln y_{t}+\left(b_{2}-d\right) \ln y_{t}^{p}+e_{t}$

where $e_{t}=v_{f}+w_{t}$. Note that the sign of the coefficient of potential income can be either positive or negative, depending on the relative sizes of $b_{2}$ and d. Intuitively, one can think of this sign being positive or negative, depending on the gradual changes in the demand for imports over time. If structural changes lead to a more open economy, with an increased proportion of imports in relation to income, this coefficient should be positive, and vice-versa.

Finally, a third variable normally found in import equations is the time trents. The inclusion of this variable may be justified on theoretical grounds as accounting for long run changes in the economy and consequentially in the structure of imports ${ }^{11}$. Again, the sign of its coefficient could be either positive or negative, depending on how successful is the import substitution process. A time trend has also been used as an explanatory variable in the models that adopt the production theory approach. Koilli (1978), for example, uses a time trend to account for structural changes in both import demand and export supply functions

One should note that although these variables may improve the fit of the equation, in theoretical terms there is not much that can be said, since in all cases the expected sign of the coefficients is not clear. Even in the case of capacity utilization, it has been argued that a negative sign can be seen as appropriate If the domestic business cycle follows the same pattern as the world economy, then it seems possible that an increase in capacity utilization will lead to a reduction in imports, since domestic producers can supply faster than foreign ones. ${ }^{12}$

Morenver, as shown by Barker (1979), since potential output is usually calculated as a function of time, these three variables are interconnected. Despite the different economic interpretation that is given to justify the use of such variables, it seems that they are ail capturing the same phenomenon. It is our view that variables such as the potential product and the time trend may be accounting for structural changes in the demand for impurts that cannot be accommodated by the assumption of fixed coefficients

\subsubsection{Export equations}

Exactly as in import equations, it is also common to include other variables such as capacity utilization, potential product or a time trend in export equations

Goldstein and Khan (1978) developed a model where the potential product is one of the explanatory variables in the supply of exports. The idea is that exports should respond positively to changes in the country's capacity to produce. Their model, with some alterations, can be defined as

11 See, for example, Weisskoff (1979).

12 Akhtar (1981) and Barker (1987) found evidence of a negative relation between capacity utilization and imports for the British economy. 


$$
\begin{aligned}
& \ln X^{d}=a_{0}+a_{1} \ln \left[P_{X}\left(1+T^{*}\right) / P_{d}^{*}\right]+a_{2} \ln Y^{*} \\
& \ln X^{s}=b_{0}+b_{1} \ln \left[E P_{X}(1+S) / P_{d}\right]+b_{2} \ln Y^{p} \\
& a_{2}, b_{1}, b_{2}>0, a_{1}<0
\end{aligned}
$$

This model can also be used to justify the presence of potential product, as well as other variables such as capacity utilization, in the reduced form equation. Solving (27) for $P_{X}$ we obtain

$$
\begin{aligned}
& \ln P_{x}=c_{0}+c_{1} \ln X^{d}+c_{2} \ln \left(1+T^{*}\right)+c_{3} \ln P_{d}^{*}+c_{4} \ln Y^{*} \text { where, } \\
& c_{0}=-a_{0} / a_{1}, c_{1}=1 / a_{1}, c_{2}=-1, c_{3}=1, c_{4}=-a_{2} / a_{1} \\
& c_{3}, c_{4}>0, c_{1}, c_{2}<0
\end{aligned}
$$

Substituting (29) into (28) and assuming market clearance, we have

$$
\ln X=\left(b_{0}+b_{1} c_{0}\right) / D+b_{2} / D \ln Y^{p}+b_{1} c_{4} / D \ln Y^{*}+b_{1} / D \ln \left[E P_{d}^{*}(1+S) / P_{d}\left(1+T^{*}\right)\right]
$$

where, $L=1-b_{1} c_{1}$

Since $D$ is positive, the coefficients are all expected to be positive. Similarly, one can get the reduced form for prices by solving (28) and (29) for $P_{x}$.

$$
\begin{aligned}
\ln P_{x} & =\left(c_{0}+c_{1} b_{0}\right) / D+1 / D \ln \left[P_{d}^{*} /\left(1+T^{*}\right)\right]+c_{4} / D \ln Y^{*}+c_{1} b_{2} / D \ln Y^{p} \\
& +c_{1} b_{1} / D \ln \left[E(1+S) / P_{d}\right]
\end{aligned}
$$

As noted above, one could use this same framework to introduce capacity utilization. It is normally argued that the supply of exports depends negatively on the level of capacity utilization. The central argument is that producers always serve the home market first, because foreign markets are presumably less profitable due to more costly marketing, transport costs or greater risk. Therefore $b_{2}$ would be negative. Winters (1981) and Hotson and Gardiner (1983) adopt this approach.

A different approach to the inclusion of capacity utilization was adopted by Batchelor (1977) and Brakman and Joosten (1986). According to them, because producers prefer to serve the home market first, individual exporting firms are subject to two different regiries When the level of capacity utilization is low, exports will be constrained by external demand, but when it is high, exports will be constrained hy domestic supply. There is then a threstiold point such that as overall capacity utilization rises "factors influencing demand - world trade and competition prices became suddenly unimportant and those influencing supply - investment, profitability - become suddenly all important."13 In analytical terms the model can be described as

${ }^{13}$ Batchelor (1977), p.43 


$$
\begin{aligned}
x & =\min \left(x_{1}, x_{2}\right) \\
x_{1} & =a_{1}\left(Y^{f}, P / P^{f}\right)+b_{1} q \\
x_{2} & =a_{2}\left(K, P / P^{h}\right)+b_{2} q \\
p & =c_{1}\left(P^{f}\right)+d_{1} q \quad \text { if } x=x_{1} \\
& =c_{2}\left(P^{h}\right)+d_{2} q \quad \text { if } x=x_{2}
\end{aligned}
$$

where, $x_{1}$ is the demand for exports, $x_{2}$ is the export supply, $Y^{\prime}$ is real foreign income, $K$ is the net stock of capital of the firm, $P, P^{f}$ and $P^{h}$ are the export price of the firm, price of competing goods and home market price respectively, and $q$ is the capacity utilization rate.

Taking an individual firm, it has to be operating in the demand or supply constraint case, but for the economy as a whole there can exist both demand and supply constrained firms. Therefore for a firm there will be a threshold point ( $q$ ) where it jumps between regimes, but for the economy such jumps are clearly implausible. Observations cannot be fully characterized as belonging to one or the other regime, but rather as helpful in describing both regimes Obviously, one observation will tell more about the supply constraint case once $\mu_{q}$, the average of $q$ for all firms, is less than $q^{\prime}$ and vice-versa

Given a distribution function for the capacity utilization $\mathrm{g}(\mathrm{q})$, which has a expected value of $\mu_{\mathrm{q}}$, the volume of exports for the economy is ( a similar equation could be written for export prices as well)

$$
\begin{aligned}
X & =\int_{-\infty}^{+\infty} x g(q) d q \\
& =\int_{-\infty}^{q^{+}} x_{1} g(q) d q+\int_{q^{\prime}}^{+\infty} x_{2} g(q) d q
\end{aligned}
$$

To make the model operational we just have to add a disturbance term to the equations and specify the form of the distribution function $g(q)$. One will then end up with a siingle equation that can be estimated by ordinary least squares, being the parameters in both regimes retrievable from this "reduced form". ${ }^{14}$

A time trend has also been used in export models, although its theoretical justification is sometimes not very convincing. In studies on the UK economy, the basic justification for using time is the long term reduction in the UK's share of world exports. ${ }^{15}$ The idea is that British exports have been subjected to a iong term nonprice loss of competitiveness, so that the coefficient on the time trend will have negative sign.

\footnotetext{
14 Another approach to the estimation of this problem based in switching regressions is suggested by Goldfeld and Quandt (1973a and 1973b).

15 See, for example, Dinenis et alii (1989) or Brooks (1981).
} 


\subsection{Some econometric considerations}

When estimating trade equations, as in other economic relations, one faces several econometric problems, such as choice of functional form, simultaneity, dynamic specification, stability of the parameters and aggregation problems

\subsubsection{Functional form}

Almost all empirical work on trade equations is based on a log linear specification. The evidence in favour of the log linear specification in import demand was first provided by Khan and Ross (1977) and later confirmed by Boylan et alii (1980), both using the Box and Cox methodology. More recently Hitiris and Petoussis (1984), using a methodology developed by Godfrey and Wickens (1981) that allows for serial correlation, again come out in favour of the log linear specification. In terms of export equations, this problem has normally been dealt with by assumption.

\subsubsection{Dynamics and stationarity}

To account for the fact that the full response of the dependent variable to changes in the explanatory variables may not be completed in the same period, different dynamic models have been used. Perhaps the two most popular ones are the partial adjustment and the polynomial distributed lag models.

Although the use of dynamic specifications seems essential when working with quarterly data, the evidence suggest that most of the adjustment occurs within a year. Goldstein and Khan $(1976,1978)$, for example, have estimated that the average lag of total imports is between two and four quarters, while for exports it is between one and five quarters. If one is considering disaggregated data, the problem can be more complicated once some goods, especially capital goods, are subject to longer delivery lags

Another noteworthy observation is that normally a "specific to general" approach has been adopted. It is common to start with simple models that are subsequently expanded to solve the problems that emerge. As shown by Hendry and Mizon (1978), this is not the most adequate way to proceed, once iive test performed in the new model is conditional on the result of the tests done in the former model. ${ }^{16}$

A mcre adequate and elegant way of dealing with the question of model dynamics is to adopt an error correction model (ECM). In the ECM the estimation of the long and short run coefficients is done separately. The long run coefficients, also called cointegrating vector, are obtained in a first stage by either the Engle and Granger two step method or the Johansen procedure. These coefficients are then used in the second stage when only the short run responses are estimated This approach is used in Portugal (1992).

In addition, the ECM is also a good answer to the question of non-stationarity. All the empirical work on the Brazilian trade equations have assumed, implicitly, that the

\footnotetext{
${ }_{17}^{16}$ An exception is Hitiris and Petoussis (1984), who adopt a "general to specific approach".

17 A more detailed theoretical discussion of the ECM, unit roots, cointegration and the Engle and Granger and Johansen procedures can be found in Portugal (1992).
} 
variables of interest are stationary. ${ }^{18}$ If the variables are non-stationary but cointegrated then the ECM is the proper model to use. ${ }^{19}$

\subsubsection{Simultaneity}

As noted above it has been more common to use simultaneous models for exports, using the "small country" hypothesis to justify the estimation of the demand equation alone in the case of imports. A better procedure, however, would be the specification of a complete model that could be tested for price exogeneity.

Although the simultaneity between prices and quantities is ruled out by the "small country" assumption, simultaneity can still be a problem in relation to imports and income. Considering an extended model, the level of imports can be seen as an explanatory variable in the income equation. This is especially true in the case of essential imports. For a country where essential goods represent a large proportion of total imports, a simultaneity problem should be expected even in the total imports equation. Most of the literature ignores this problem, failing to even test for the endogeneity of income.

\subsubsection{Aggregation}

The possibility of an aggregation bias in trade equations was first discussed by Orcult (1950). He argued that goods with low price elasticity can display a larger price variation, causing a downward bias in the estimated aggregate price elasticity of demand. Actually, there can exist a specification bias as well. As Maddala (1977) points out, each aggregate coefficient is a weighted average, not only of its own individual values, but of all coefficients in the regression. In other words, unless all the individual elasticities are equal, the disaggregated price elasticity should be a weighted average of the individuals price and income elasticities.

On the other hand, disagaregated equations should also be preferred on the grounds of using all the informatioir available In the absence of misspecification problems or measurement errors, the use of disaggregated data should be preferred because there is no loss of information. In practice, however, it is possible that disaggregated data will have larger measurement error than aggregated data, and that the specification of demand functions is iikely to be more difficult in the disaggregated equations. ${ }^{21}$

If one decicies to work with disaggregated equations Barker (1970), using a demand for imports, offers a simple way to obtain the aggregated price and income elasticities. When using a log linear specification, the disaggregated elasticities contribute according to the share of the individual import in total imports and the relative variation of the individual demand over that of total demand.

\footnotetext{
${ }^{18}$ The unit root tests carried out in Portugal (1992) show that all Brazilian series used in the estimation of trade equations are indeed non-stationary.

${ }_{19}$ SEe Engle and Granger (1987).

${ }^{20}$ Exception is Moraes (1986), who estimates a simultaneous model.

21 See Aigner and Goldfeld (1974). Winters (1980) has found evidence indicating that aggregated models explain total exports better than disaggregated ones.
} 


$$
b_{a}=\sum_{i=1}^{n} b_{i} M_{i} / M_{a}\left[\frac{d X_{i} / X_{i}}{d X_{a} / X_{a}}\right]
$$

The ratio of relative own variation over relative total variation is the so called "distribution factor". If all goods vary in the same way as the aggregate, that is, the distribution factor is one for all goods, then the aggregated coefficient is just a simple weighted average of the individual coefficients as in the linear case. ${ }^{22}$

\subsubsection{Parameter stability}

A common assumption in econometrics is constancy of coefficients. In terms of trade equations, it implies that price and income elasticities are constant over time A first challenge to this assumption was made by Orcutt (1950), arguing that parameter instability could arise due to the "quantum effect". The idea is that buyers have some kind of inertia in switching suppliers, in such a way that small and large variations of prices have different impacts on demand If we have a sample that contains periods of both small and large variation of prices, then we sinould estimate the equation und $\epsilon_{i}$ two different regimes. ${ }^{23}$

Other more important sources of instability are the government trade policy, changes in the pattern of trade due to the process of economic development, and sudden shocks such as changes in the exchange rate regime, large increase in oil prices, etc. Note that instability can either result in sharp changes in the coefficients, as a consequence of sudden shocks, or in smooth changes over time, resulting from the process of economic development and on the long run implementation of trade policy.

Together with these secular and sharp changes in the elasticities it is also possible to find some cyclical variation. In the case of the income elasticity, for example, changes in the composition of output over the business cycle may induce it to have a kind of cyclical behaviour ${ }^{24}$

Several authors have tested trade equations for structural change in the parameters The evidence in most cases is in favour of structural change ${ }^{25}$ In none of the cases though, the coefficient path over time was actually estimated

As far as Brazil is concerned, the question of parameter instability should be expected to be very important As discussed in the Portugal (1992), Brazil has experienced several important changes in the trade policy regime. Such changes are bound to have had some effect on the trade elasticities. Moreover, the import substitution plans carried out in the beginning of the 1950 s and 1960 s changed substantially the structural composition of Brazilian industry, which again could have affected the parameters stability.

\footnotetext{
22 To obtain the distribution factors, one can run auxiliary regressions of $l_{n} x_{i}$ on $l_{n} x_{a}$.

23 Learner and Stern (1970) redefine this problem in terms of speed of adjustment, that is demand will adjust faster to large variation of prices than to small ones.

${ }^{24}$ Evidence that the relation between total import and expenditure is not stable uver the business cycle was found by Giovannetti (1987).

${ }^{25}$ See, for example, Mastropasqua (1982) for the Italian case, Joy and Stolen (1975) and Stern et alii (1979) for the United States and Abreu (1987) and Fachada (1990) using Brazilian data.
} 


\section{BRAZILIAN TRADE EQUATIONS}

In this section, we present and discuss the empirical work available on trade equations in Brazil. We concentrate our attention on nine papers: Weisskoff (1979), Abreu and Horta (1982), Dib (1985), Abreu (1987) and Fachada (1990) on demand for imports, and Braga ad Markwald (1983) and Paula Pinto (1982), Fachada(1990) and Zini (1988) on export equations.

Two types of assessment can be undertaken The first is concerned with econometric modelling issues and the second with the discussion and comparison of results. As far as econometric modelling is concerned, all the empirical work in question is open to the same kind of criticism of how to deal with dynamics and stationarity and residual correlation. The series are implicitly assumed to be stationary and the treatment of dynamics does not go further than the partial adjustment model. In almost all the cases a strong residual correlation is present and is "corrected" by using the Corchrane-Orcutt technique. Moreover, the inclusion of some kind of a time trend or a trend like variable is often necessary to obtain reasonable results. Therefore the main focus in this section will not be the econometric criticism of the papers instead, we will concentrate in the comparison and discussion of the available empirical literature.

\subsection{Import demand equations}

We use the results presented by Dib (1985) to highlight the point about the use of variables such as capacity utilization, potential output and time trend to improve the fit of the equation. Table 1 presents various experiments with different specifications done by Dib (1985). To solve the autocorrelation problem in equation 1 she tries basically to use different combinations of the capacity utilization, potential output and time variables. The theoretical questions concerning this kind of variables were discussed previously

Table 1- Demand elasticities - Dib (1985) - $1960 / 80$

\begin{tabular}{c|c|c|c|c|c}
\hline equation & income & $\begin{array}{c}\text { pctencial } \\
\text { output }\end{array}$ & $\begin{array}{c}\text { capacity } \\
\text { utilization }\end{array}$ & time & price \\
\hline 1 & 1509 & - & - & - & -0.751 \\
2 & 3.293 & -2.232 & - & - & -1.128 \\
3 & 3.291 & - & - & -0.155 & -1.129 \\
4 & - & - & 3.292 & 0.074 & -1.128 \\
5 & 1.061 & - & 3.232 & - & -1.128 \\
6 & - & 1.061 & 3.293 & - & -1.128 \\
\hline
\end{tabular}

Source: Dib (1985).

Note that price and income elasticities in equations 2 and 3 are almost identical, reflecting the fact that potential output is constructed just as a function of time. They are measuring, as Weisskoff would argue, the import substitution process, or, as 1 would argue, long run changes in the coefficients caused by the import substitution process.

On the other hand, the inclusion of the capacity utilization variable in equation 5 substantially changes the income elasticity, from 3.29 to 1.06 . As argued before this 
variable is used to explain cyclical movements in import demand. Therefore, the reduction in the income elasticity could be associated with the separation between the cyclical and secular effects.

She also tries to introduce some dynamics into the equation via a partial adjustment model, but in the end, for forecasting purposes, chooses equation 5 as the best model.

As can be gleaned from tables 2 and 3 , the comparison of the results presented by Abreu and Horta (1982) and Abreu (1987) seems to show little change in the magnitude of price and income elasticities in the equations estimated for the periods $1961 / 80$ and $1960 / 87$. However, the elasticity of imports with respect to capacity utilization changes considerably for intermediate and capital goods. Even for total imports, Abreu (1987) shows that the capacity utilization elasticity would also change substantially if we did not incorporate the dummy variable for 1974 into the equation.

According to Abreu (1987), this large change in the capacity utilization elasticity is due to measurement problems in this variable. In the construction of potential output, a constant rate of growth is built in, in his case $7.58 \%$. However, because of the severe adjustment program in the period 1981-83, it is not plausible to suppose a continuous growth of potential output at the same rate as before. Therefore, the constructed capacity utilization variable would overestimate the true spare capacity in the economy. Note that if capacity utilization is actually part of the true specification, this measurement problem could be overcome by a time varying parameter model. The measurement error could be compensated by allowing the capacity utilization elasticity to vary.

Table 2 - Demand Elasticities - Abreu (1987) - 1960/85

\begin{tabular}{c|c|c|c|c}
\hline & income & $\begin{array}{c}\text { capacity } \\
\text { utilization }\end{array}$ & $\frac{\text { debt }}{\text { reserves }}$ & price \\
\hline Total & 1.074 & 2.593 & - & -0.685 \\
intermediate goods & 0.999 & 2.152 & - & -0.538 \\
consumer goods & 0.813 & - & -0.219 & - \\
capital goods & 1.085 & 3.389 & - & -0.638 \\
\hline
\end{tabular}

Source: Abreu (1987).

A better way of approaching this problem is to use a measure of capacity utilization that allows for a time varying potential output growth rate. This question is addressed in more detail in Portugal (1992), where different measures of capacity utilization are calculated and compared.

As reported in table 4, Abreu (1987) also shows that even the income and price elasticities cannot be regarded as constant over this period. Experiments using recursive least squares for the period 1969/1985, showed that the income and price elasticities changed smoothly during this period, while the capacity utilization elasticity changed from 3.40 to 2.59 . 
Table 3 - Demand Elasticity - Abreu and Horta (1982) - 1961/1980

\begin{tabular}{l|c|c|c|c} 
& income & $\begin{array}{c}\text { capacity } \\
\text { utilization }\end{array}$ & $\frac{\text { debt }}{\text { reserves }}$ & price \\
\hline Total & 0.947 & 2.762 & - & -0.754 \\
intermediate goods & 1.130 & 1.106 & - & -0.566 \\
consumer goods & 1.279 & - & - & -0.337 \\
capital goods & 0.995 & 5.072 & - & -0.666 \\
\hline
\end{tabular}

Source: Abreu and Horta (1982)

An interesting comparison can be made between the results of Abreu (1987) and Weisskoff (1979), because disaggregated estimates are available for two substantially different periods of time. It should be said that the estimated price and income elasticities are not totally comparable, not only since the specifications are slightly different, but also because Abreu (1987) excludes crude oil and wheat from the total and intermediate goods equations.

Nevertheless, the differences in the elasticities are quite considerable in the total imports equation Weisskoff's income elasticity is more than twice Abreu's reported value. For the price elasticity this relation is the other way around. The differences are particularly substantial in the capital and intermediate goods case. These changes may be associated with long run change in the elasticities, due to the import substitution process and alterations in exchange rate management. ${ }^{26}$

Table 4 - Demand Elasticities - Abreu (1987) - 1960/85 Recursive Least Squares Estimation

\begin{tabular}{|c|c|c|}
\hline & price & income \\
\hline & $\begin{array}{l}-0.844 \\
(0096)\end{array}$ & $\begin{array}{c}0.981 \\
(0061)\end{array}$ \\
\hline $1960 / 80$ & $\begin{array}{l}-0.852 \\
(0.088)\end{array}$ & $\begin{array}{c}0.974 \\
(0.052)\end{array}$ \\
\hline $1960 / 81$ & $\begin{array}{r}0.864 \\
(0.082)\end{array}$ & $\begin{array}{c}0.961 \\
(0.043)\end{array}$ \\
\hline $1960 / 82$ & $\begin{array}{c}-0.864 \\
(0.077)\end{array}$ & $\begin{array}{c}0.961 \\
(0.037)\end{array}$ \\
\hline $1960 / 83$ & $\begin{array}{c}-0.734 \\
(0.097)\end{array}$ & $\begin{array}{c}0.032 \\
(0.043)\end{array}$ \\
\hline $1960 / 84$ & $\begin{array}{c}-0.701 \\
(0.101)\end{array}$ & $\begin{array}{c}1.058 \\
(0.048)\end{array}$ \\
\hline $1960 / 85$ & $\begin{array}{c}-0.685 \\
(0.106)\end{array}$ & $\begin{array}{c}1.074 \\
(0.050)\end{array}$ \\
\hline
\end{tabular}

Source: Abreu (1987).

Finally, let us make some consideration on quarterly estimates. Some work has been done receniiy on import equations using quarterly data. The earlier lack of such estimates was mainly due to the absence of GDP data on a quarterly basis. Since such a GDP series became available for the period 1975-85, Abreu (1987), Moraes (1986), Fachada (1990) and Zini (1988) have fitted import demand equations using quarterly data.

${ }^{26}$ This question is addressed in more detail by Portugal (1992). 
The quarterly data estimations are done in the same unsatisfactory fashion as the annual estimations. Although all the variables are in levels, no attempt is made to test for unit roots. The question of residual autocorrelation is dealt with by using the Cochrane-Orcutt procedure. The question of dynamics is also not properly treated. Although one should expect to have some dynamics when dealing with quarterly data, most of the estimations presented are static equations. Whenever some dynamics is introduced it is done via the simple partial adjustment model. As a result of all this modelling problems the use of a time trend is quite frequent.

Table 5 - Demand Elasticities - Weisskoff (1979) - 1953/1970

\begin{tabular}{l|c|c|c}
\hline & income & time & price \\
\hline Total & 2.33 & -0.13 & -0.37 \\
consumer goods & 2.19 & -0.13 & $-0.27^{1}$ \\
metallic intermediate & 2.75 & -0.13 & -0.42 \\
non-metallic intermediate & 2.01 & -0.09 & 0.41 \\
capital equip. for agriculture & 6.11 & -0.34 & -1.28 \\
capital equip. for industry & 5.29 & -0.29 & -1.16 \\
\hline
\end{tabular}

Source: Weisskoff (1979).

Note: 1) not significant at $5 \%$.

The results and problems of Abreu (1987) and Moraes (1986) are similar to those we have just presented. Therefore, given space limitations these papers will not be discussed.

It should be noticed that Zini (1988) also presents import demand estimations using quarterly data. Nevertheless, since his disaggregation of imports is not compatible with the one mostly used in the current Brazilian literature, including Portugal (1992), we decided not to show or discuss his estimates. The important thing to notice about Zini's work is the improvement in the modelling aspect. Instead of simply correcting the residual autocorrelation he tries to distinguish between model misspecification and residual autocorrelation. He uses a testing procedure based on a first order autocorrelation test and the RESET test developed by Thursby (1981).

Table 6 - Demand Elasticities - Fachada (1990) - 76.4/88.4

\begin{tabular}{l|c|c|c|c} 
& income & $\begin{array}{c}\text { capacity } \\
\text { utilization }\end{array}$ & $\begin{array}{c}\text { time } \\
\text { trend }\end{array}$ & price \\
\hline Total & 1.610 & 2.120 & -0.013 & -0.510 \\
intermediategoods & 1.161 & 2.884 & - & -0.873 \\
capital goods & 0.701 & 0.855 & -0.014 & -0.599 \\
\hline
\end{tabular}

Source: Fachada (1990)

Some criticism of this test procedure by Knottnerus (1985) and Godfrey (1987) have cast doubts on the robustness of the diagnostic checks. Moreover, this procedure does not deal with the question of non-stationarity. 


\subsection{Export equations}

Unlike the empirical work on import demand equations, econometric studies on Brazilian export equations have been quite unsystematic and, therefore, comparisons between different works are more difficult. Until recently, almost all the empirical work available was based on reduced forms or, in a few cases, on supply equations only.

Studies using a reduced form equation do not allow us to retrieve the supply and demand elasticities. This is because the complete model is normally not specified, since the main objective in these works has been forecasting. On the other hand, supply elasticities that are obtained from studies that use the small country hypothesis can also be inadequate. If the price elasticity of demand is not infinite, single equation models that ignore the demand side will produce biased and inconsistent estimates.

Braga and Markwald (1983) and Paula Pinto (1982) using annual data have found some evidence to refute the hypothesis of infinite price elasticity of demand for manufactured goods. This result is somehow surprising since the Brazilian share in the world exports is quite small. For the period 1950/1985, the Brazilian share of world exports was around $1.32 \%$. It should be noticed though that in the case of Braga and Markwald (1983) the evidence against the small country hypothesis is not very conclusive. As can be seen in table 7 the price elasticity of demand is quite high.

Table 7 shows a selection of the results presented by Paula Pinto (1982) and Braga and Markwald (1983). They both estimate simultaneous models for the periods 1957/75 and 1959/81, respectively. Although the sample period is approximately the same, there seems to be some instability in the elasticities. The difference in the price elasticity of demand and the capacity utilization elasticity are substantial, ranging from -1.12 to -6.32 , and from zero to -1.36 , respectively. The income elasticity also varies, but in a less dramatic way.

Table 7 - Demand elasticities and supply elasticities

\begin{tabular}{|c|c|c|}
\hline \multicolumn{3}{|c|}{ DEMAND FLASTICITIES } \\
\hline $\begin{array}{l}\text { Paula Pinto (1982) } \\
\text { Braga and Markwald (1983) }\end{array}$ & $\begin{array}{c}\text { income } \\
2.19 \\
3.14\end{array}$ & $\begin{array}{l}\text { price } \\
-1.12 \\
-6.32\end{array}$ \\
\hline \multicolumn{3}{|c|}{ SUPPLY ELASTICITIES } \\
\hline \multirow[b]{2}{*}{$\begin{array}{l}\text { Paula Pinto (1982) } \\
\text { Braga and Markwald (1983) }\end{array}$} & income & price \\
\hline & $\begin{array}{c}1.69 \text { to } 3.14 \\
2.20\end{array}$ & $\begin{array}{l}-0.08^{1} \\
-1.36\end{array}$ \\
\hline
\end{tabular}

Source: Paula Pinto (1982) and Braga and Markwald (1983).

Note: 1) not significant at $5 \%$. 
Table 8 - Demand elasticities and supply elasticities

\begin{tabular}{l|c|c|c}
\hline \multicolumn{4}{c}{ DEMAND ELASTICITIES } \\
\hline & & income & price \\
\hline Fachada (1990) & & 2.41 & -1.93 \\
Zini (1988) & 4.92 & -0.31 \\
\hline \multicolumn{4}{|c}{ SUPLLY ELASTICITIES } \\
\hline & price & capacity & potential \\
\hline Fachada (1990) & $0.33^{\prime}$ & utilization & output \\
Zini (1988) & $0.26^{1}$ & -2.33 & 2.91 \\
\hline
\end{tabular}

Source: Fachada (1990) and Zini (1988).

Note: 1) not significant at $5 \%$.

More recently some estimations using quarterly data have become available. Both Fachada (1990) and Zini (1988) estimate a simultaneous model for the Brazilian exports of manufactured goods. As table 8 makes clear the estimated elasticities are not similar. A possible explanation for this discrepancy is parameter instability. Zini (1988) uses data for the period 1970/1986 while Fachada's estimation are performed using data from 1976 to 1988 . To reinforce this argument note that in both cases a trend variable was used. The potential output variable present in both works was obtained by regressing the real output against the time trend.

The same kind of criticism made in the case of the import demand can also be applied for export equations. The question of dynamics does not receive adequate treatment. Even in the case of quarterly data an instantaneous adjustment or, at most, a partial adjustment model is used. Although the variables are used in levels, no test for unit roots are done. The modelling strategy consists in starting with a simple model and try to solve possible problems by generalising it. It is no surprise that serial autocorrelation is a problem in almost all the cases. As mentioned before, Zini (1990) is the only one to devute more attention to the question of modelling strategy. Nevertheless, he ends up using a non-robust method and does not address the non-stationarity problem

\section{CONCLUSIONS}

This paper presents the main theoretical issues on the trade equations and discusses the some of the empirical work applied to Brazil

We have argued that parameter instability is a fundamental issue in the Brazilian case. The parameters should be expected to vary not only during the business cycle, as a result of changes in expectations and in the composition of output, but also in response to changes in trade policy.

The analysis of the available empirical work seems to offer some evidence in favour of the hypothesis of parameter instability. This evidence in the case of imports are derived from the comparison between the results presentad by Abreu (1987) and Weisskoff (1979), the importance of the trend variables in the equations and the sample variation experiments carried out by Abreu (1987). In the exports equations case, there is also a considerable discrepancy between the estimated elasticities. 
Changes in the sample period lead to substantial changes in some of the parameters and trend variables have been used.

Despite this there has been no serious attempt to deal with this problem. The only thing that was done in this respect was to perform some structural stability tests. Whenever such tests were performed they have rejected the hypothesis of parameter stability

The testing and estimation of models allowing for parameter variation seems important not only because it could improve the forecast performance, but could also serve as an instrument to evaluate the impact of the different trade policy changes and import substitution programs. ${ }^{27}$

Moreover, there still remain questions of econometric modelling. The question of are tests for unit roots, the use of the Error Correction Mechanisms, residual autocorrelation and the modelling of short and long runs are issues that must also be addressed ${ }^{28}$

Although the production theory approach offers a integrated way of dealing with imports and exports that has strong links with trade theory and a clear microeconomic foundation, all the empirical work on Brazilian trade equations is based on the most popular imperfect substitutes model. As Kohli (1991) has shown the use of different functional forms has sometimes lead to conflicting results. This approach offers no proper framework to deal with dynamics and, moreover, the Brazilian data on price and quantity of primary domestic factors are practically nonexistent A substantial amount of work will be needed to generate data set of reasonable quality

\section{REFERENCES}

ABREU, M. de P. Equações de Demanda de Importações Revisitadas: Brasil, 1960 - 1985. Rio de Janeiro: Departamento de Economia, PUC,1986. (Textos para Discussão n. 148).

and HORTA, M. H. T. T. Demanda de Importações no Brasil, 1960-1980: Estimações Agregadas e Desagregadas por Categorias de Uso e Projeções para 1982. Rio de Janeiro: IPEAVINPES, 1982. (Texto para Discussão n. 48)

AIGNER, D J and GOLDFEID, S. M. Estimation and Prediction from Aggregate Data when Aggregates are Measured more Accurately than their Components Econometrica, $\because 42, \mathrm{p}$. 113-134, 1974

AKHTAR, M. $\dot{\sim}$ Income and price Elasticities of Non-oil Imports for Six Industrial Countries. The Manchester School, v 49, p. 334-347, 1981.

BALASSA, Bela. Trade Liberalization among Industrial Counties, New York: McGraw-Hill, 1967.

BARKER, T. S. Aggregation Error and Estimates of the UK Import Demand Function, In: HILTON, $K$ and HEATHFIELD, D. F. (ed.), The Econometric Study of the United Kingdom. London: Macmillan, 1970.

- Identification of Activity Effects, Trends and Cycles in Import Demand Oxford Bulletin of Economics and Statistics, v. 41, p. 63-68, 1979.

Exports and Imports. In BARKER, T. S. and PETERSON, W. (ed), The Cambridge Multisectorial Dynamic Model of the British Economy, Cambridge: Cambridge University Press, 1987.

BATCHELOR, R. A. A Variable Parameter Model of Exporting Behaviour, Review of Economics an Statistics, v. 44, p. 43-57, 1977.

${ }^{27}$ Portugal (1992) offers a discussion of trade policy issues.

${ }^{28}$ The estimation of a Error Correction Mechanism and the use of time varying parameter technicues based on the Kalman filter can be found in Portugal (1992). 
BOYLAN, T. A et alii. The Functional form of the Aggregate Import Demand Equation Journal of International Economics, v. 10, p. 561-566, 1980.

BRAGA, H. C. and MARKWALD, R. A. Funções de Oferta e de Demanda das Exportações de Manufaturados no Brasil: Estimação de um Modelo Simultâneo. Pesquisa e Planejamento Económico, v. 13, p. 707-743, 1983

BRAKMAN, S and JOOSTEN, G. On A Two Regime Model of the Dutch Export Market Institute of Economic Research, Faculty of Economics, University of Groningen, 1986 (Research Memorandum no. 188).

BROOKS, S. Systematic Econometric Comparations: Exports of Manufactured Goods.

National Institute Economic Review, v. 97, p. 67-80, 1981.

BURGESS, D. F. A Cost Minimization Approach to Import Damand Equations", Review of Economics and Statistics, v. 56, p. 225-234, 1974 a.

Production Theory and the Derived Demand for Imports. Journal of International Economics, v. 4, p. 103-117,1974b.

CLARK, P. G and WEISSKOF, R. Import Demand and Import Policy in Brazil. Willians College, Center for Development Economics, 1967. (Reseach Memorandum n. 8, with technical appendix).

DIB, M. de F S Importações Brasileiras: Politicas de Controle e Determinantes da Demanda Rio de Janeiro: BNDES, 1985

DIEWERT, W. E. and MORRISON, C J Export Supply and Import Demand Functions. A Production Theory Approach. In: FEENSTRA, F. C. (ed), Empirical Methods for International Trade Cambridge: MIT Press, 1989.

DINENIS, $E$ et alii. The London Business School Econometric Model: Some Recent Developments Econometric Modelling, v. 6, p. 243-251, 1989

ENGLE, R F AND GRANGER, C. W. J. Cointegration and Error Correction. Representation, Estimation and Testing, Econometrica, v. 55, p. 251-276, 1987.

ENOCH, C. A Measures of Competitiveness in international Trade. Barik of England Quarterly Bulletin, v. 18, p. 181-195, 1978.

FACHADA, J P. Um Estudo Econométrico da Balanca Comercial Brasileira: 1975-1988 Rio de Janeiro, PUC-RJ, 1990 (Dissert. Mes. Econ.)

FAIR, R. C and JAFFEE, D. M. Methods of Estimation for Markets in Disequilibrium, Econometrica, v. 40, p. 497-514, 1972.

FAIR, R C. and KELEJIAN, H H Methods of Estimation for Markets in Disequilibrium: A Further Study. Econometrica, v. 42, p 177-190, 1974.

GIOVANNETTI, G Aggregate Imports and Expenditure Components in Italy: An Econometric Analysis Cambdridge. University of Cambridge, 1987. (Research Paper no. 39).

GODFREY, L. Discriminating Between Autocorrelation and Misspecification in Regression Analysis: An Alternative Test Strategy Review of Economics and Statistics, v. 69, p 128 . 134, 1987

GODFREY, L and WICKENS, M. Testing Linear and Log-linear Regressions for Functional Form. Review of Economics and Statistics, v. 48, p 487-496, 1981.

GOLDSTEIN, M. and KHAN, M. S. Large versus Small Price Changes and Demand for Imports, IMF Staff Papers, v 23, p. 200-225, 1976.

The Surpply and Demand for Exports: A Simultaneous Approach. Review of Economics and Statistics, v. 60, p. 275-286, 1978.

Income and Price Effects in Foreign Trade. In: JONES, R. W and KENEN, P. B (ed). Handbook of International Economics. Amsterdam: North-Holland, v 2, 1985

HITIRIS, T. and PETOUSSIS, E. Price and Tariff Effects in Dynamic Specification of the Demand for Imports. Applied Econometrics, v. 16, p. 15-24, 1984.

HOTSON, A C and GARDINER, K. L. Trade in Manufactures Bank of England Technical Series, r. 5, 1983.

JOY, J. and STOLEN, J. D. The Change in US Import Demand Function from 1950's to the 1960's. Review of Economics and Statistics, v. 57, p. 109-111, 1975.

KHAN, M. S and ROSS, K. Z. Cyclicai and Secular Income Elasticities of the Demand for 
Imports. Review of Economics and Statistics, v. 57, p. 357-361, 1975.

The Functional form of the Aggregate Import Demand Equation. Journal of Intemational Economics, v. 7, p. 149-160, 1977.

KHAN, M. S. Import and Export Demand in Developing Countries, IMF Staff Papers, v. 21, p 678-693, 1974

KNOTTNERUS, P A Test for Discriminating Between Autocorrelation and Misspecification in Regression Analysis: A Critical Note. Review of Economics and Statistics, v.67, p.175-77, 1985.

KOHLI, U. R. A Gross National Production Function and the Derived Demand of imports and Supply of Exports. Canadian Journal of Economics, v. 11, p. 167-182, 1978.

Technology, Duality and Foreign Trade: The GNP Function Approach to Modeling Imports and Exports. London: Harvester Wheatsheaf, 1991

LAWRENCE, D. A. Export Supply and Import Demand Elasticities. University of British Columbia, Canada, 1987. (PhD Thesis).

LEANNER, E. E. and STERN, R. M. Quantitative International Economics Boston: Ally and Bacon, 1970.

MACKINNON, J G. Model Specification tests Against Non-Nested Alternatives Econometric Reviews, v. 2, p. 85-110, 1983.

MADDALA, G. S. Econometrics. New York: McGraw-Hill, 1977.

-. Disequilibrium, Self-Selection and Switching Models In: GRILICHES, Z; INTRILIGATOR, M. (eds.). Handbook of Econometrics Amsterdam: Elsevier Puilishers, v. 3, 1986.

MAGEE, S. P. Prices, Incomes, and Foreign Trade. In: KENEN, P. B. (ed), International Trade and Finance. Cambridge: Cambridge University Press, 1975.

MASTROPASQUA, C Was there a Structural Change in the Italian Demand for Aggregate Imports? The Evidence from Quarterly Data, 1960-1979, Economic

Notes, v. 1, p. 65-72, 1982.

MODIANO, E. M. Conseqüências Macroeconômicás da Restrição Externa de 1983: Simuláções com um Modelo Econométrico para a Economia Brasileira. Rio de Janeiro: Departamento de Economia, PUC, 1983. (Textos Discussão n. 49).

MORAES, P. B. Uma Nota Sobre as Importaçōes Brasileiras de Produtos Manufaturados. Rio de Janeiro: Departamento de Economia, PUC, 1986. (Texto para Discussão n 114)

ORCUTT, G. Measurement of Price Elasticities in International Trade. Review of Economics and Statistics, V. 32, p. 117-132, 1950

PAULA PINTO, M. B Politica Cambial, Politica Salarial e o Potencial das Expotações de Manufaturados Relatório PNPE, 1982.

PORTUGAL, Marcelo S. Brazilian Foreign Trade: Fixed and Time Varying Parameter Models, unpublished PhD Thesis, University of Warwick, 1992.

QUANDT, R. E. The Econometrics of Disequilibrium. New York: Basil Blackwell, 1983

RAMOS, $L$. Niveis de Demanda e Necessidades de Importação de Petróleo e Derivados Uma Análise Prospectiva. Pesquisa e Planejamento Econômico, v. 14, n. 2, 1985

RIOS, S. P. Um Modelo de Desequilibrio para as Exportações Brasileiras de Produtos Manufaturados. Rio de Janeiro: PUC, 1986. (Dissertação de mestrado)

STERN, R. M., et alii. Evidence of Structural Change in the Demand for Aggregate US Imports and Exports. Journal of Political Economy, v. 87, p. 179-192,1979.

TRASLOSHEROS, J G. Dernandas de Importações Agregadas de Capital e de Bens de Consumo Intermediário (exceto Petróleo e Trigo), Brasil: 1975.1 - 1985.4. Rio de Janeiro: PUC, 1986. (Dissertação de mestrado).

THURSBY, J. G. A Test Strategy for Discriminating Between Autocorrelation and Misspecification in Regression Analysis: An Alternative. Review of Economics and Statistics, v. 63, p. 117-123, 1981.

WEISSKOFF, R. Trade. Protection and Import Elasticities for Brazil. Review of Economic and Statistics, v. 61, p. $58-66,1979$

WINTERS, L. A Aggregation in Logarithmic Models: Some Experiments with UK Exports Oxford Bulletin of Economics and Statistics, v. 42, p. 2S-50, 1980. 
An Econometric Model of the Export Sector. Cambridge University Press, 1981.

WOODLAND, A. D. International Trade and Resource Allocation. Amsterdam: North Holland, 1982.

ZINI Jr, A. A. Exchange Rate Policy and Stabilization in Brazil, unpublished PhD Thesis, Cornell University, 1988 .

\section{SINOPSE}

\section{EQUILIBRIUM MODELS OF TRADE EQUATIONS: A CRITICAL REVIEW}

Neste artigo, revisa-se a literatura teórica sobre equações de comércio exterior, inclusive o modelo de comércio baseado na teoria da produção. Discute-se vários problemas comumente encontrados em trabalhos empíricos e também a literatura existente sobre equações relativas ao comércio exterior brasileiro. 